\title{
Patch of hair in the hyoid region
}

\author{
Katarina Kieselova, Felicidade Santiago, Martinha Henrique
}

Department of Dermatology, Centro Hospitalar Leiria, Leiria, Portugal

\section{Correspondence to}

Dr Katarina Kieselova,

katarinakieselova@gmail.com

Accepted 3 December 2016

\section{DESCRIPTION}

An 8-year-old previously healthy girl, was referred to our clinic with a symptom of a tuft of terminal hair on the anterior neck region (figures 1 and 2). The underlying skin had no pigmentary changes. According to the parents, the localised hair had started to appear at 1 year of age and there was no history of preceding trauma, inflammation, radiation or use of topical and systemic drugs. Complete physical examination, including neurological and ophthalmological examination, did not reveal other comorbidities. Her parents were not consanguin-

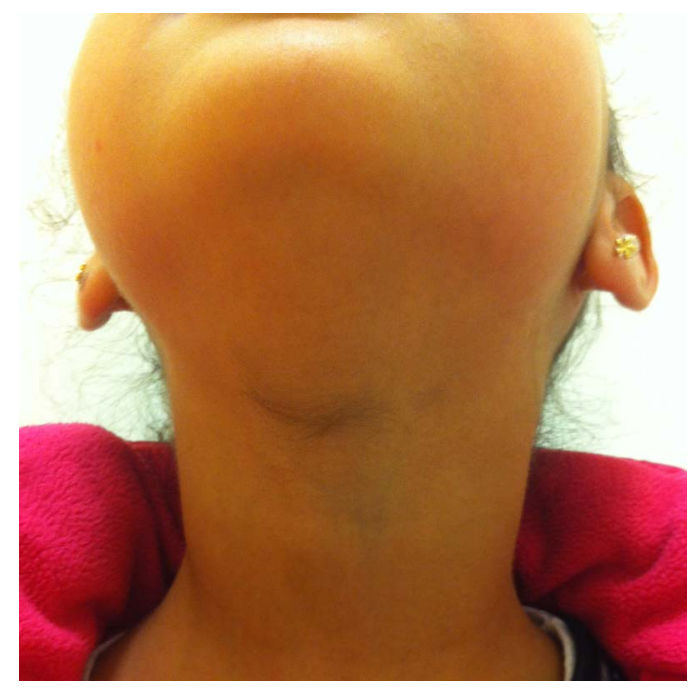

Figure 1 A tuft of terminal hair on the anterior neck: anterior view.

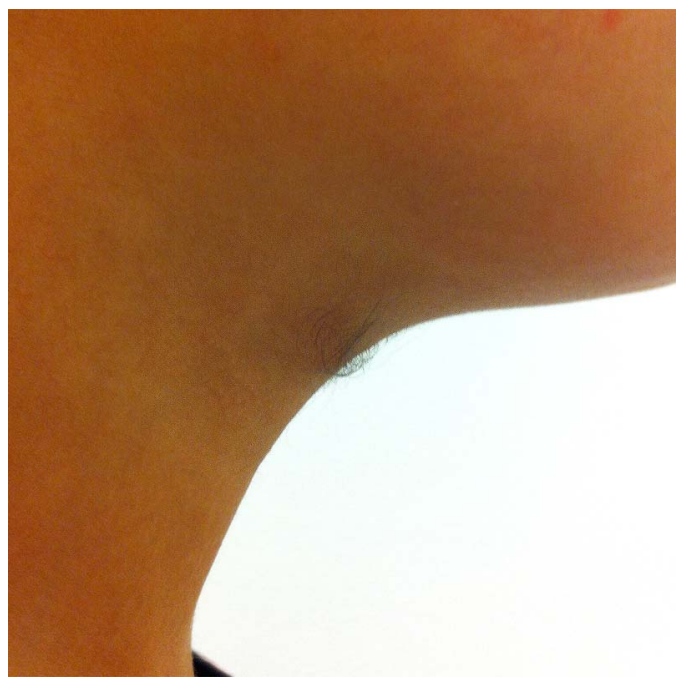

Figure 2 Lateral view. eous and the family history was negative for this disorder. Clinical features were consistent with the diagnosis of anterior cervical hypertrichosis $(\mathrm{ACH})$ or hairy throat syndrome, which is a rare form of local hair growth at the midline of the neck.

$\mathrm{ACH}$ occurs at birth or during early childhood and it can be acquired or congenital, although the inheritance pattern remained to be determined. Among the reported cases, there is a significant female predominance. For most of the affected patients, this anomaly represents only an aesthetic problem; however, in some cases ACH may be a part of a more complex disorder $(22.5 \%$ of reported cases). ${ }^{1}$ The most common associated disorders reported in the literature involve neurological abnormalities (mental retardation, peripheral sensory and motor neuropathy), ophthalmological disorders (optic atrophy and chorioretinal changes), hallux valgus and dorsal hypertrichosis. ${ }^{12}$

\section{Learning points}

Anterior cervical hypertrichosis ( $\mathrm{ACH}$ ) may be only an isolated finding, not affecting the healthy development of the child. Nonetheless, it may be a sign of an underlying condition, including neurological and ocular disorders.

- In order to recognise this rare entity it is imperative to provide detailed physical examination and clinical history to exclude the associated abnormalities that may be present in patients with $\mathrm{ACH}$.

- As the most cases of ACH represent only a cosmetic problem for the patient, simple hair removal is recommended.

Contributors KK and FS made the diagnosis and performed the complete investigation and were involved in the management of the patient. KK and FS wrote the manuscript and performed the literature search. FS and MH corrected the manuscript and gave conceptual advice. All authors read and approved the final version of the manuscript.

Competing interests None declared.

Patient consent Obtained.

Provenance and peer review Not commissioned; externally peer reviewed.

\section{REFERENCES}

1 Megna M, Balato N, Patruno C, et al. Anterior cervical hypertrichosis: a case report and review of the literature. Pediatr Dermatol 2015;32:252-5.

2 Meziane M, Bessis D, Amraoui N, et al. [Sporadic anterior cervical hypertrichosis]. Ann Dermatol Venereol 2014;141:211-14. 
Copyright 2016 BMJ Publishing Group. All rights reserved. For permission to reuse any of this content visit http://group.bmj.com/group/rights-licensing/permissions.

BMJ Case Report Fellows may re-use this article for personal use and teaching without any further permission.

Become a Fellow of BMJ Case Reports today and you can:

- Submit as many cases as you like

- Enjoy fast sympathetic peer review and rapid publication of accepted articles

- Access all the published articles

Re-use any of the published material for personal use and teaching without further permission

For information on Institutional Fellowships contact consortiasales@bmjgroup.com

Visit casereports.bmj.com for more articles like this and to become a Fellow 